\title{
ELASMOBRANCH BYCATCH ON ARTISANAL TRAMMEL NET FISHERY IN THE CANARY ISLANDS
}

\author{
José Carlos Mendoza*, Carmelo Dorta, \\ Alberto Brito \& José Carlos Hernández
}

\begin{abstract}
In this work we studied an artisanal trammel net fishery targeting red stripped mullet Mullus surmuletus. Catches and discards were evaluated on 30 fishings trials using 3 experimental net mesh sizes around 2 fishing grounds at the East coast of Tenerife (Canary Islands). A total of 48 species were identified with $M$. surmuletus, axillary seabream Pagellus acarne and parrotfish Sparisoma cretense, being the most frequently captured. Catches and discards represented $89.77 \%$ and $10.23 \%$, respectively, of total catch weight. Experimental mesh sizes showed a clear decrease in the proportion of abundance catches caught as mesh size increased. Elasmobranchs were represented in high percentages reaching $37.61 \%$ of total catch weight. European Union protected angel shark Squatina squatina was also caught during the experimental fishings and represented $51.14 \%$ of the elasmobranch total catch weight. Findings of the study are intended to contribute to increasing knowledge about the artisanal fishing and allow suggestions to be made on fishing practices that will reduce future catches of the European Union protected elasmobranchs.
\end{abstract}

KEYwORds: bycatch, discard, Squatina squatina, artisanal fishery, Canary Islands.

\section{CAPTURA INCIDENTAL DE ELASMOBRANQUIOS EN LAS PESQUERÍAS CON TRASMALLO EN LAS ISLAS CANARIAS}

\section{RESUMEN}

En este trabajo hemos estudiado una pesquería artesanal con trasmallo que tiene como especie objetivo al salmonete Mullus surmuletus. Evaluamos las capturas en 30 pescas experimentales con tres tamaños de malla diferentes y en dos zonas de pesca en la costa este de Tenerife (islas Canarias). Un total de 48 especies fueron identificadas, siendo las especies $M$. surmulletus, el besugo Pagellus acarne y la vieja Sparisoma cretense, las más capturadas. Las capturas y descartes representaron el $89,77 \%$ y $10,23 \%$, respectivamente, del peso de las capturas totales. A medida que aumentamos el tamańo de malla utilizada se observó una clara disminución en las proporciones de abundancias de las capturas. Los elasmobranquios estuvieron representados en un porcentaje alto, alcanzando $37,61 \%$ del peso de las capturas totales. El angelote Squatina squatina, protegido por la Unión Europea, fue también capturado durante las pescas experimentales y representó el $51,14 \%$ del peso de las capturas totales. Los resultados de este estudio pretenden contribuir al incremento del conocimiento de las pesquerías artesanales y permiten realizar sugerencias sobre las prácticas de pesca que puedan reducir en un futuro las capturas de los elasmobranquios protegidos por la Unión Europea.

Palabras Clave: captura accidental, descarte, Squatina squatina, pesca artesanal, islas Canarias. 


\section{INTRODUCTION}

Worldwide, many species are captured by a variety of fishing gears and discard rates are high. Discarding occurs for a number of reasons such as specimens have little or no commercial value, are in poor condition and are below the legal size (Hall et al. 2000). Other discarding reasons are fishing boats storage capacity, high grading or sorting ability of the crew (Clucas 1996). Discarding practices are affected by bycatch composition, which are determined by environmental and social factors (Catchpole et al. 2005). In general, bycatch and subsequent discarding is unavoidable due to size selectivity of different gears and mixed-species fisheries. Thus, the relative importance of discards depends largely on the gear, the gear characteristics (e.g. mesh size, hanging ratios), fishing strategies, marketing constraints and legislation (e.g. Hall, 1996).

Most small-scale fisheries around the world have no management strategies in place and when existent they are based on landings data which do not take into consideration bycatch or discards (Lleonart and Maynou 2003; Merino et al. 2008). Artisanal trammel net fisheries are among the most significant small-scale fisheries in southern Europe (Erzini et al. 2001) and several studies have shown that discard rates from trammel nets are higher than other static gears like longlines or gill nets (Borges et al. 2001).

Elasmobranch fish are a common component of the bycatch and discard from fisheries (Bonfil 1994). Elasmobranchs are also vulnerable to overexploitation due to life strategies (Brito et al. 1998; Pratt and Casey 1990; Smale and Goosen 1999; Wintner and Cliff 1999; Hazin et al. 2002; Coelho and Erzini 2002). These life strategies are defined by a number of factors that characterize elasmobranchs: large maximum body size, slow growth, late maturation (at a large size) and long lifespan. (Walker and Hislop 1998; Dulvy et al. 2000; Stevens et al. 2000; Frisk et al. 2001).

Bycatch of elasmobranch is unmanaged in most fisheries and elasmobranchs are less able to sustain their populations under fishing pressures that are sufficient to sustain many teleost species for which most fishing quotas have been designed (Heuter 1998). Most elasmobranchs are predators at or near, the top of marine food webs, and as such they play a fundamental role in the structure and trophic functioning of the ecosystem (Cortés 1999; Stevens et al. 2000). Most studies on bycatch and discards of elasmobranchs have considered only trawl and longline fisheries (Stobutzki et al. 2002; Carbonell et al. 2003; Clarke et al. 2005; Megalofonou et al. 2005; Coelho and Erzini 2008); few have focused on trammel net fisheries and none of these have been carried out in southern Atlantic waters.

Angel sharks Squatina squatina Linnaeus, 1758 are highly susceptible to bycatch in trawls and trammel nets as they are bottom-dwelling (Couch 1822; Day 1880-1884). Squatina squatina has been fully protected in European waters since January 2011, and capture, retain onboard, transship and landing is forbidden by

* Departamento de Biología Animal, Geología y Edafología. Universidad de La Laguna, Tenerife, Canary Islands, Spain. Corresponding author: jcmendoza85@gmail.com. 
European Union regulation n. ${ }^{\circ} 44 / 2012$. To manage bycatch and conserve vulnerable species we need better knowledge of discard rates from different fishing gears and to evaluate the impacts on population, trophic and ecosystem dynamics (Hall et al. 2000; Borges et al. 2001).

Trammel nets are highly represented by Canary Island artisanal fisheries but catches and related bycatch have never been studied around Tenerife's coastline (BOC 2005/04). The trammel net fishery of Candelaria harbor has 9 authorized artisanal fishing boats and a restricted fishing season from February to March. Red strippet mullet Mullus surmuletus Linnaeus, 1758 was the target species of the studied fishery, but it is known that additional species are accidentally caught by the nets. Bycatch in this area consists of a wide range of species including elasmobranchs with commercial value as the angel shark (S. squatina) and Smooth-hound Mustelus mustelus Linnaeus, 1758. The main objectives of this study were: (1) to characterize an experimental trammel nets in fishing areas where trammel net fishery is allowed in Tenerife island, and (2) to contribute to improvement of the trammel net artisanal fishery by suggesting how different mesh sizes could be used to reduce bycatch and discards.

\section{MATERIAL AND METHODS}

\subsection{STUDY AREA}

The sampling area is located off the southeast coast of Tenerife (Canary Islands) at a latitude between $28^{\circ} 11-22^{\prime} \mathrm{N}$ and $16^{\circ} 21-25^{\prime} \mathrm{W}$, in the municipality of Candelaria (fig. 1). The average wind speed at the sampling sites ranged from: 7.77 - 17.4 knots $(11.6 \pm 1.67)$. Experimental fishings were performed with good sea conditions (2-3 Beaufort wind force scale). Sampling was carried out using a $5 \mathrm{~m}$ (length) artisanal fishing boat from Candelaria and a 2-3-person crew. Fishing grounds were selected by scientists in order to cover the whole fishing area where trammel net is allowed and separated in two grounds, one to the north of Candelaria and one to the south.

\subsection{EXPERIMENTAL DESIGN}

To study the development of experimental fishings we collected all data relating to the fishing area, duration of fishing, fishing effort, catch composition, catch size and catch weight. Normal fishing practices were followed from February 2010 to March 2010. During experimentation the same observer accompanied a single crew for one full day. Fishing took place over 10 fishing days aboard the same artisanal fishing boat ( $\mathrm{LaOrCa}$ ) on 2 fishing areas (north and south). In each fishing day, three experimental trammel nets with different net mesh sizes $(50,60$ and $80 \mathrm{~mm})$, were used simultaneously with 2 or 4 panel nets each. Trammel nets were set between 10 and $40 \mathrm{~m}$ depth in experimental fishing grounds where the scientist chose previously. A total of 30 deployments, 18 and 12 at North and South areas, respectively, were observed in total. The total length of each the panel nets was $70 \mathrm{~m}$. After retrieving 


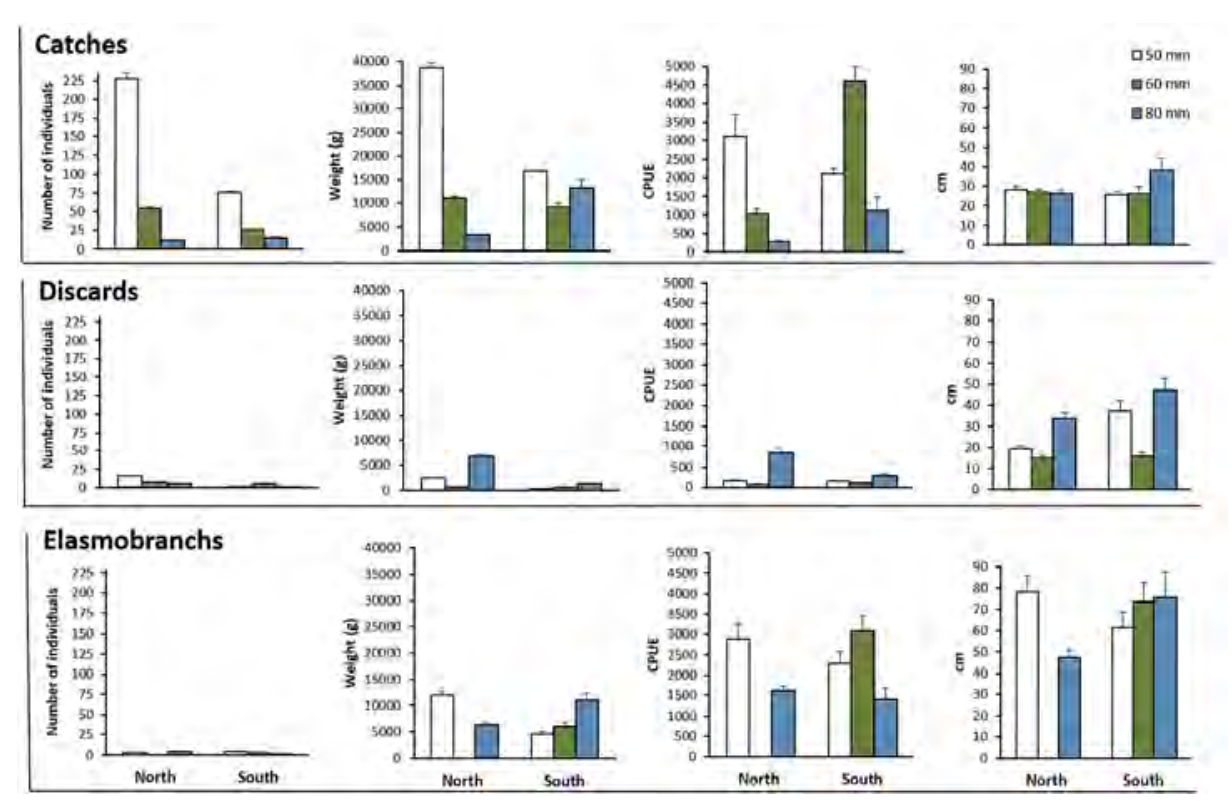

Figure 1. Mean abundance, weight $(\mathrm{g})$, length $(\mathrm{cm})$ and CPUE of catches, discards and elasmobranchs for the three different experimental mesh sizes in the artisanal trammel net fishery off the east coast of Tenerife (Canary Islands).

each net, specimens were untangled from the net by the fishermen who then decided which fish to retain and which to discard. The crew retained all fish that had some commercial value to supplement their Mullus surmuletus fishery income; among these were several fish including axillary seabream Pagellus acarne Risso, 1827 and parrotfish Sparisoma cretense Linnaeus, 1758, the common octopus Octopus vulgaris Cuvier, 1797 and the common cuttlefish Sepia officinalis Linnaeus, 1758.

Specimens were discarded if they were damaged, of little or no commercial value or below the legal catch size. All discards were identified and length (TL) and weight were recorded.

\subsection{Data analyses}

Total catch was recorded for each of the 30 experimental fishings. All specimens caught were sorted in catches or discards under fishermen judgment, identified to species level, counted, weighed (total weight, $\mathrm{g}$ ) and measured (total length, $\mathrm{cm}$ ). Analyses of variance were performed using Primer $6+$ Permanova software in order to evaluate the effect of mesh size and fishing ground on catch abundance, weight, length and CPUE (Capture Per Unit of Effort). Catch per unit of fishing effort was the total catch divided by the total amount of number of net panels used (2 or 4). Capture abundance and weight were standardized to one panel net or sample unit. Data regarding each specimen caught were analyzed after being ascribed to one of 


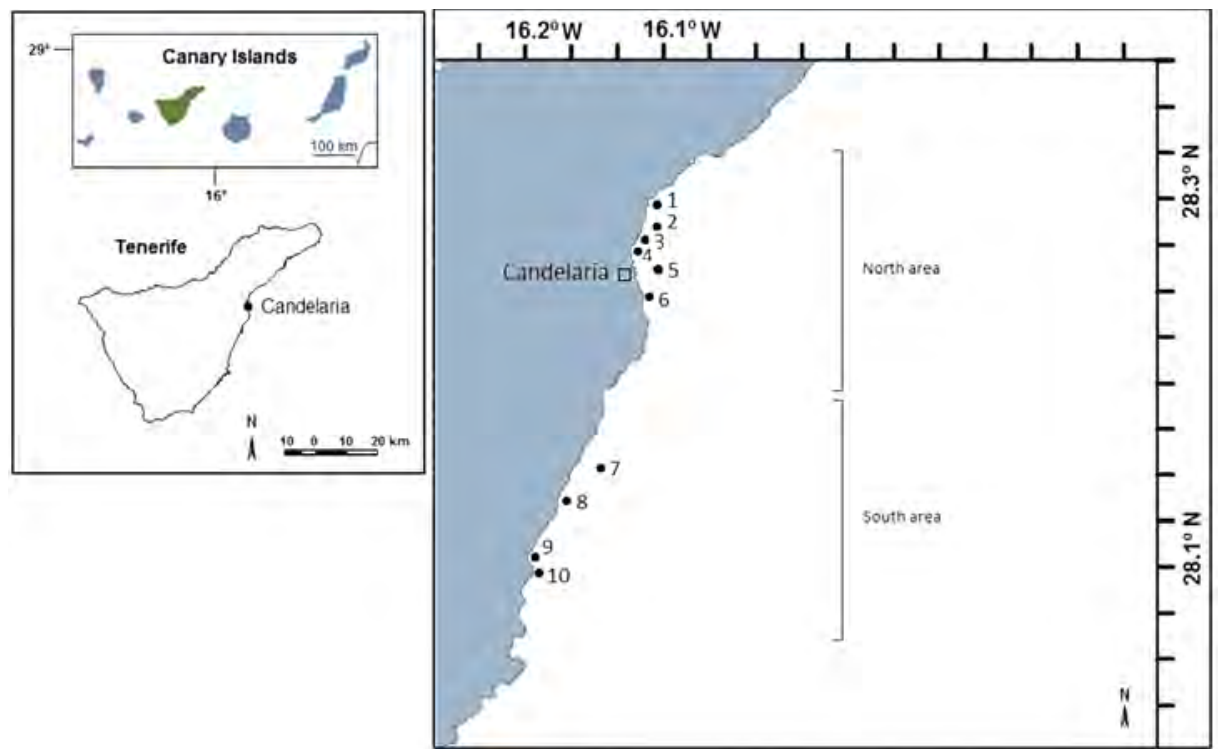

Figure 2. Location of experimental fishing grounds off the east coast of Tenerife, Canary Islands. North Area: 1) Central de Caletillas (28 $\left.\left.22^{\prime} 27^{\prime \prime} \mathrm{N}, 16^{\circ} 21^{\prime} 20^{\prime \prime} \mathrm{W}\right), 2\right)$ Cueva de La Barca $\left.\left(28^{\circ} 21^{\prime} 55^{\prime \prime} \mathrm{N}, 1^{\circ} 21^{\prime} 31^{\prime \prime} \mathrm{W}\right), 3\right)$ Cabezo del Pozo (2821' $\left.27^{\prime \prime} \mathrm{N}, 1^{\circ} 22^{\prime} 02^{\prime \prime} \mathrm{W}\right)$, 4) La playa de Candelaria (28 $\left.21^{\prime} 17^{\prime \prime} \mathrm{N}, 16^{\circ} 22^{\prime} 04^{\prime \prime} \mathrm{W}\right)$ 5) Cabezo la Barca $\left(28^{\circ} 22^{\prime} 04^{\prime \prime} \mathrm{N}, 16^{\circ} 21^{\prime} 17^{\prime \prime} \mathrm{W}\right)$ and

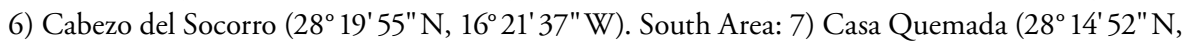
$\left.16^{\circ} 23^{\prime} 13^{\prime \prime} \mathrm{W}\right)$, 8) Los Barrancos (28 $\left.13^{\prime} 56^{\prime \prime} \mathrm{N}, 16^{\circ} 24^{\prime} 22^{\prime \prime} \mathrm{W}\right)$, 9) Recodo de la Hondura $\left(28^{\circ} 12^{\prime} 04^{\prime \prime} \mathrm{N}, 16^{\circ} 25^{\prime} 24^{\prime \prime} \mathrm{W}\right)$ and 10$)$ La Punta de la Hondura (28 $\left.11^{\prime} 48^{\prime \prime} \mathrm{N}, 16^{\circ} 25^{\prime} 11^{\prime \prime} \mathrm{W}\right)$.

two groups: catches and discards. Since elasmobranchs received particular emphasis in this study, additional analyses were carried out for individual elasmobranch species. When the number of permutations was very low, a Monte Carlo Test was used to estimate the p-value (Anderson 2001).

\section{RESULTS}

A total of 48 species were identified during the experimental fishings (table 1). In terms of weight, catches of Mullus surmuletus (26.83\%) was higher than that of any other species, followed by Squatina squatina (19.23\%). When considering the number of individuals caught, the most abundant species in catches were $M$. surmuletus, Pagellus acarne and Sparisoma cretense. A total of 5 elasmobranch species were caught (17 specimens; 40,730 g.). Among these were 2 Rajiforms, 1 Torpediniform, 1 Carchariniform and 1 Squatiniform, accounting for $37.61 \%$ of the total catch weight. Mustelus mustelus was the most abundant species, representing $52.94 \%$ of the total elasmobranch catches. In terms of weight, S. squatina made up $51.14 \%$ of the total elasmobranch catches. The number of catches and discards declined as net mesh size was increased from $50 \mathrm{~mm}$, to $60 \mathrm{~mm}$ to $80 \mathrm{~mm}$ (fig. 2). 


\begin{tabular}{|c|c|c|c|c|c|c|c|}
\hline \multicolumn{8}{|c|}{$\begin{array}{c}\text { TABLE 1. TOTAL CATCHES FOR SPECIES CAUGHT DURING THE E } \\
\text { FISHING USING TRAMMEL NETS ABOARD 'LA ORCA' OFF THE } \\
\text { OF TENERIFE (CANARY ISLANDS) }\end{array}$} \\
\hline \multicolumn{8}{|c|}{ CATChes } \\
\hline \multirow{3}{*}{$\begin{array}{c}\begin{array}{c}\text { Mesh SIZE } \\
(\mathrm{mm})\end{array} \\
\\
50\end{array}$} & \multirow[t]{2}{*}{ SPECIES } & \multicolumn{2}{|c|}{ SPeCimens } & \multicolumn{4}{|c|}{ Total Сатсн } \\
\hline & & Number & $(\%)$ & Weight (g) & $(\%)$ & $\begin{array}{r}\text { Mea } \\
(\mathrm{cn}\end{array}$ & $\begin{array}{l}\text { ngth } \\
\text { SD }\end{array}$ \\
\hline & Boops boops & 1 & 0.21 & 80 & 0.07 & 22.5 & - \\
\hline 50 & Chromis limbata & 11 & 2.35 & 549 & 0.51 & 14.4 & \pm 0.97 \\
\hline 50 & Diplodus vulgaris & 2 & 0.43 & 339 & 0.31 & 22 & \pm 0.71 \\
\hline 50 & Mullus surmuletus & 173 & 36.89 & 24350 & 22.49 & 22.1 & \pm 1.19 \\
\hline 50 & Mustelus mustelus & 5 & 1.07 & 4600 & 4.25 & 61.5 & \pm 4.27 \\
\hline 50 & Pagellus acarne & 78 & 16.63 & 6320 & 5.84 & 18.6 & \pm 1.16 \\
\hline 50 & Pagellus erythrinus & 2 & 0.43 & 430 & 0.40 & 23 & \pm 1.41 \\
\hline 50 & Pagrus pagrus & 3 & 0.64 & 462 & 0.43 & 23.3 & \pm 5.13 \\
\hline 50 & Promethichthys prometheus & 1 & 0.21 & 300 & 0.28 & 44.5 & - \\
\hline 50 & Pseudocaranx dentex & 2 & 0.43 & 2200 & 2.03 & 55 & \pm 1.41 \\
\hline 50 & Sarpa salpa & 1 & 0.21 & 150 & 0.14 & 23 & - \\
\hline 50 & Sepia officinalis & 4 & 0.85 & 842 & 0.78 & 15.8 & \pm 4.57 \\
\hline 50 & Serranus atricauda & 2 & 0.43 & 240 & 0.22 & 21.5 & \pm 1.41 \\
\hline 50 & Squatina squatina & 1 & 0.21 & 10830 & 10.00 & 107 & - \\
\hline 50 & Sparisoma cretense & 9 & 1.92 & 2300 & 2.12 & 24.7 & \pm 4.07 \\
\hline 50 & Spondyliosoma cantharus & 1 & 0.21 & 150 & 0.14 & 23.5 & - \\
\hline 50 & Synapturichthys kleini & 1 & 0.21 & 200 & 0.18 & 31.5 & - \\
\hline 50 & Synodus saurus & 3 & 0.64 & 707 & 0.65 & 30.8 & \pm 2.57 \\
\hline 60 & Bodianus scrofa & 1 & 0.21 & 250 & 0.23 & 26 & - \\
\hline 60 & Boops boops & 7 & 1.49 & 578 & 0.53 & 20.7 & \pm 3.46 \\
\hline 60 & Chromis limbata & 4 & 0.85 & 157 & 0.15 & 14.3 & \pm 1.71 \\
\hline 60 & Diplodus puntazzo & 1 & 0.21 & 104 & 0.10 & 16.5 & - \\
\hline 60 & Diplodus sargus cadenati & 1 & 0.21 & 78 & 0.07 & 16.1 & - \\
\hline 60 & Diplodus vulgaris & 3 & 0.64 & 581 & 0.54 & 21.8 & \pm 6.25 \\
\hline 60 & Lithognathus mormyrus & 1 & 0.21 & 200 & 0.18 & 26 & - \\
\hline 60 & Mullus surmuletus & 22 & 4.69 & 3907 & 3.61 & 23.4 & \pm 1.69 \\
\hline 60 & Mustelus mustelus & 4 & 0.85 & 6200 & 5.73 & 73.5 & \pm 19.69 \\
\hline 60 & Pagellus acarne & 12 & 2.56 & 886 & 0.82 & 18.7 & \pm 1.16 \\
\hline 60 & Pagellus erythrinus & 5 & 1.07 & 1459 & 1.35 & 25.4 & \pm 2.38 \\
\hline 60 & Pagrus auriga & 1 & 0.21 & 198 & 0.18 & 23.5 & \\
\hline 60 & Pagrus pagrus & 1 & 0.21 & 239 & 0.22 & 25 & \\
\hline 60 & Promethichthys prometheus & 2 & 0.43 & 400 & 0.37 & 46.3 & \pm 1.06 \\
\hline
\end{tabular}




\begin{tabular}{|c|c|c|c|c|c|c|c|}
\hline 60 & Pseudocaranx dentex & 1 & 0.21 & 90 & 0.08 & 19 & \\
\hline 60 & Sarpa salpa & 6 & 1.28 & 2500 & 2.31 & 16 & \pm 2.06 \\
\hline 60 & Sepia officinalis & 5 & 1.07 & 954 & 0.88 & 19.2 & \pm 4.62 \\
\hline 60 & Sparisoma cretense & 10 & 2.13 & 2700 & 2.49 & 25.3 & \pm 2.99 \\
\hline 60 & Sphyraena viridensis & 2 & 0.43 & 690 & 0.64 & 51.8 & \pm 7.42 \\
\hline 60 & Spondyliosoma cantharus & 2 & 0.43 & 202 & 0.19 & 19.8 & \pm 1.06 \\
\hline 60 & Synodus saurus & 4 & 0.85 & 1339 & 1.24 & 30.5 & \pm 5.93 \\
\hline 80 & Balistes capriscus & 2 & 0.43 & 1100 & 1.02 & 32 & \pm 4.24 \\
\hline 80 & Boops boops & 9 & 1.92 & 800 & 0.74 & 21.1 & \pm 0.70 \\
\hline 80 & Mullus surmuletus & 4 & 0.85 & 800 & 0.74 & 22.9 & \pm 2.68 \\
\hline 80 & Pagellus erythrinus & 1 & 0.21 & 100 & 0.09 & 21.5 & - \\
\hline 80 & Sarpa salpa & 1 & 0.21 & 233 & 0.22 & 26 & - \\
\hline 80 & Scorpaena scrofa & 1 & 0.21 & 1600 & 1.48 & 24 & - \\
\hline 80 & Squatina squatina & 1 & 0.21 & 10000 & 9.24 & 104 & - \\
\hline 80 & Sparisoma cretense & 3 & 0.64 & 273 & 0.25 & 33 & \pm 2.78 \\
\hline 80 & Synodus saurus & 4 & 0.85 & 1700 & 1.57 & 36.1 & \pm 3.97 \\
\hline \multicolumn{8}{|c|}{ DiscaRDS } \\
\hline 50 & Abudefdufluridus & 3 & 0.64 & 216 & 0.20 & 13 & \pm 0.00 \\
\hline 50 & Aulostomus strigosus & 1 & 0.21 & 300 & 0.28 & 57 & - \\
\hline 50 & Bothus podas & 3 & 0.64 & 180 & 0.17 & 17.7 & \pm 0.58 \\
\hline 50 & Polymixia nobilis & 1 & 0.21 & 80 & 0.07 & 18.5 & - \\
\hline 50 & Pomadasys incises & 4 & 0.85 & 350 & 0.32 & 18.9 & \pm 0.85 \\
\hline 50 & Scorpaena canariensis & 1 & 0.21 & 34 & 0.03 & 12 & - \\
\hline 50 & Scorpaena notate & 3 & 0.64 & 189 & 0.17 & 14.5 & \pm 1.73 \\
\hline 50 & Stephanolepis hispidus & 3 & 0.64 & 266 & 0.25 & 15.7 & \pm 1.15 \\
\hline 50 & Synodus synodus & 2 & 0.43 & 300 & 0.28 & 25 & \pm 1.41 \\
\hline 50 & Taeniura grabata & 1 & 0.21 & 1200 & 1.11 & 49.5 & - \\
\hline 60 & Bothus podas & 5 & 1.07 & 206 & 0.19 & 14.8 & \pm 2.54 \\
\hline 60 & Trigloporus lastoviza & 1 & 0.21 & 100 & 0.09 & 23 & - \\
\hline 60 & Scorpaena canariensis & 2 & 0.43 & 331 & 0.31 & 19.5 & \pm 4.95 \\
\hline 60 & Scorpaena maderensis & 5 & 1.07 & 166 & 0.15 & 11.8 & \pm 1.10 \\
\hline 60 & Stephanolepis hispidus & 3 & 0.64 & 222 & 0.21 & 14.8 & \pm 1.04 \\
\hline 60 & Synodus synodus & 1 & 0.21 & 179 & 0.17 & 27.5 & - \\
\hline 60 & Trachinus radiates & 3 & 0.64 & 599 & 0.55 & 23.8 & \pm 13.4 \\
\hline 80 & Bothus podas & 1 & 0.21 & 83 & 0.08 & 19 & - \\
\hline 80 & Dasyatis pastinaca & 1 & 0.21 & 1300 & 1.20 & 50 & - \\
\hline 80 & Taeniura grabata & 1 & 0.21 & 1200 & 1.11 & 47 & - \\
\hline 80 & Torpedo marmorata & 3 & 0.64 & 5400 & 4.99 & 45.2 & \pm 4.80 \\
\hline
\end{tabular}


Captures obtained with $50 \mathrm{~mm}$ mesh trammel nets consisted of 28 different species: 1 cephalopod, 3 elasmobranchs and 24 bony fish, plus some other invertebrates (primarily sea urchins and corals) (table 1). Catches reached $93.16 \%$ in terms of abundance and $95.07 \%$ of total weight. Discards reached $6.84 \%$ in terms of abundance and $4.93 \%$ of total weight. Although elasmobranchs made up only a small percentage of the total catch in number $(2.17 \%)$, due to the size of individuals in this group they accounted for a high percentage of total catch weight $(28.59 \%)$.

Using nets of $60 \mathrm{~mm}$ mesh size a total of 28 different species were captured: 1 cephalopod, 1 elasmobranch and 26 bony fish (table 1). Catches reached $82.60 \%$ in terms of abundance and $92.93 \%$ of total weight. Discards reached $17.40 \%$ in terms of abundance and $7.07 \%$ of total weight. Elasmobranchs reached only $3.31 \%$ of total catch size (24.29\% of total catch weight).

The $80 \mathrm{~mm}$ mesh trammel nets captured a total of 13 different species: 4 elasmobranchs and 9 teleosts (table 1). The most numerous species was bogue Boops boops Linnaeus, 1758 , followed by $M$. surmuletus. Catches reached $81.25 \%$ in terms of abundance and $67.53 \%$ of total weight. Discards reached $18.75 \%$ in terms of abundance and $32.47 \%$ of total weight. Elasmobranchs represented $18.76 \%$ of the total individual catch which equated to $72.79 \%$ of total catch weight.

There were no significant effects of any source of variation between catches, discards and elasmobranchs (table 2) including for the elasmobranch species (table 3).

\section{DISCUSSION}

The results obtained in this study revealed that there was a great number of species caught in this trammel net fishery. The number of catches declined significantly as net mesh size was increased from $50 \mathrm{~mm}$, to $60 \mathrm{~mm}$ to $80 \mathrm{~mm}$, a result that was consistent across all of the studied fishing ground areas. The decrease in catches by the larger mesh net can be attributed to the fact that abundance generally declines exponentially with size (e.g., Jennings et al. 2001). The results obtained revealed a clear effect of mesh size on catches but results obtained for discards were less clear and no clear management action regarding elasmobranch can be derived from the usage of different mesh size.

The diversity of species caught by trammel nets in the current study was probably due to the variety of mechanisms by which these nets work to catch fish gilling, wedging, entangling and pocketing (Erzini et al. 2006). In total 21 different species were discarded by the fishery, a number which constituted $10.23 \%$ of the total catch abundance. Discard rates are lower in small scale static fisheries (such as those using trammel nets) compared to larger scale fisheries using active gear: $37 \%$ (Monteiro et al. 2001) to $70 \%$ for deepwater crustacean trawlers (Borges et al. 2001), $62 \%$ for trawlers (Borges et al. 2001; Erzini et al. 2002), and 50.5\% for demersal purse seiners (Gonçalves et al. 2004). However, lower mean discard rates (27\%) have also been reported for pelagic purse seiners (Borges et al. 2001; Erzini et al. 2002). Discard rates recorded here were lower to those reported in other studies of artisanal trammel net bycatch (e.g 15 - 49\% in Iberian Peninsula waters, Gonçalves 


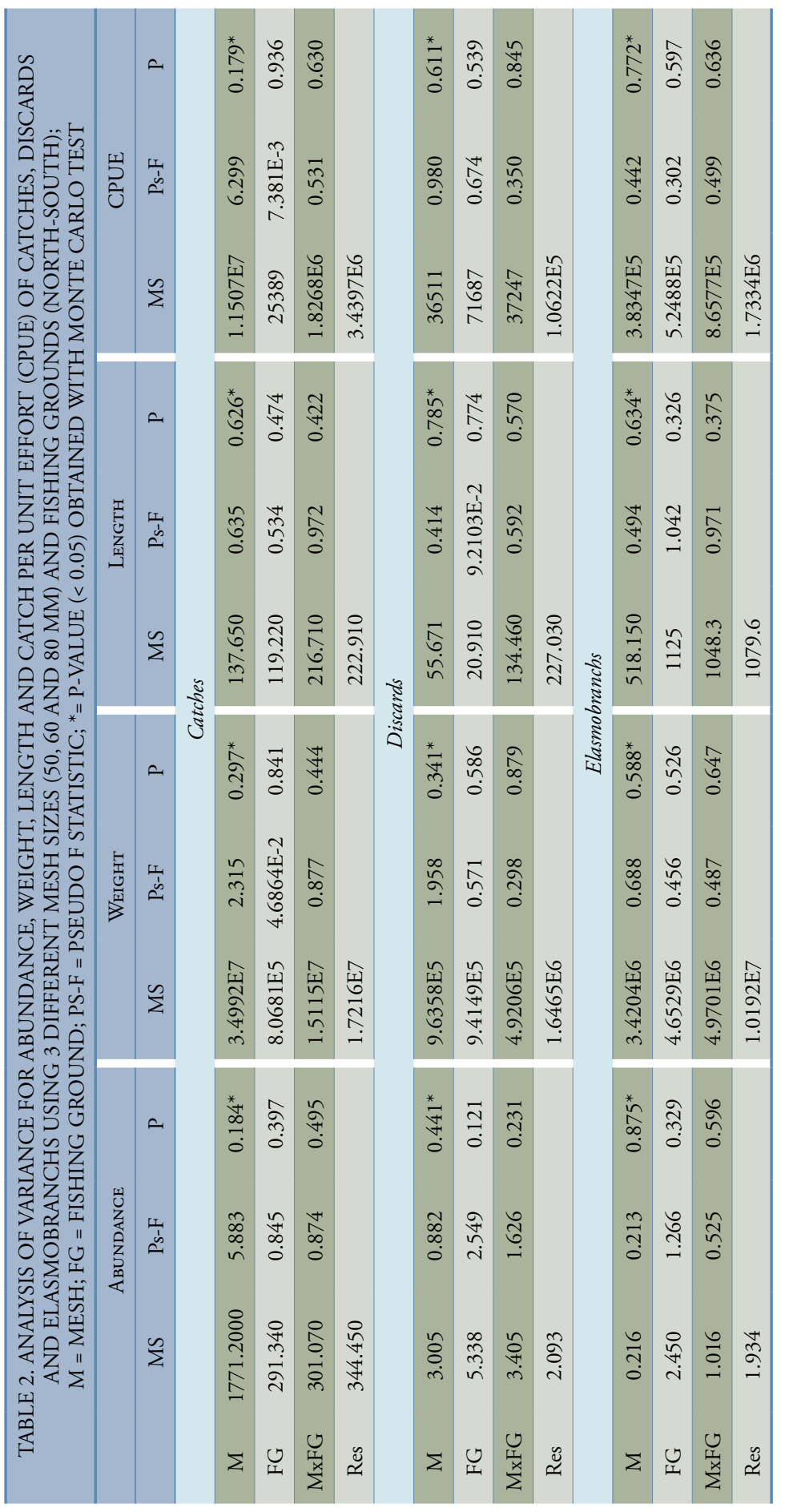




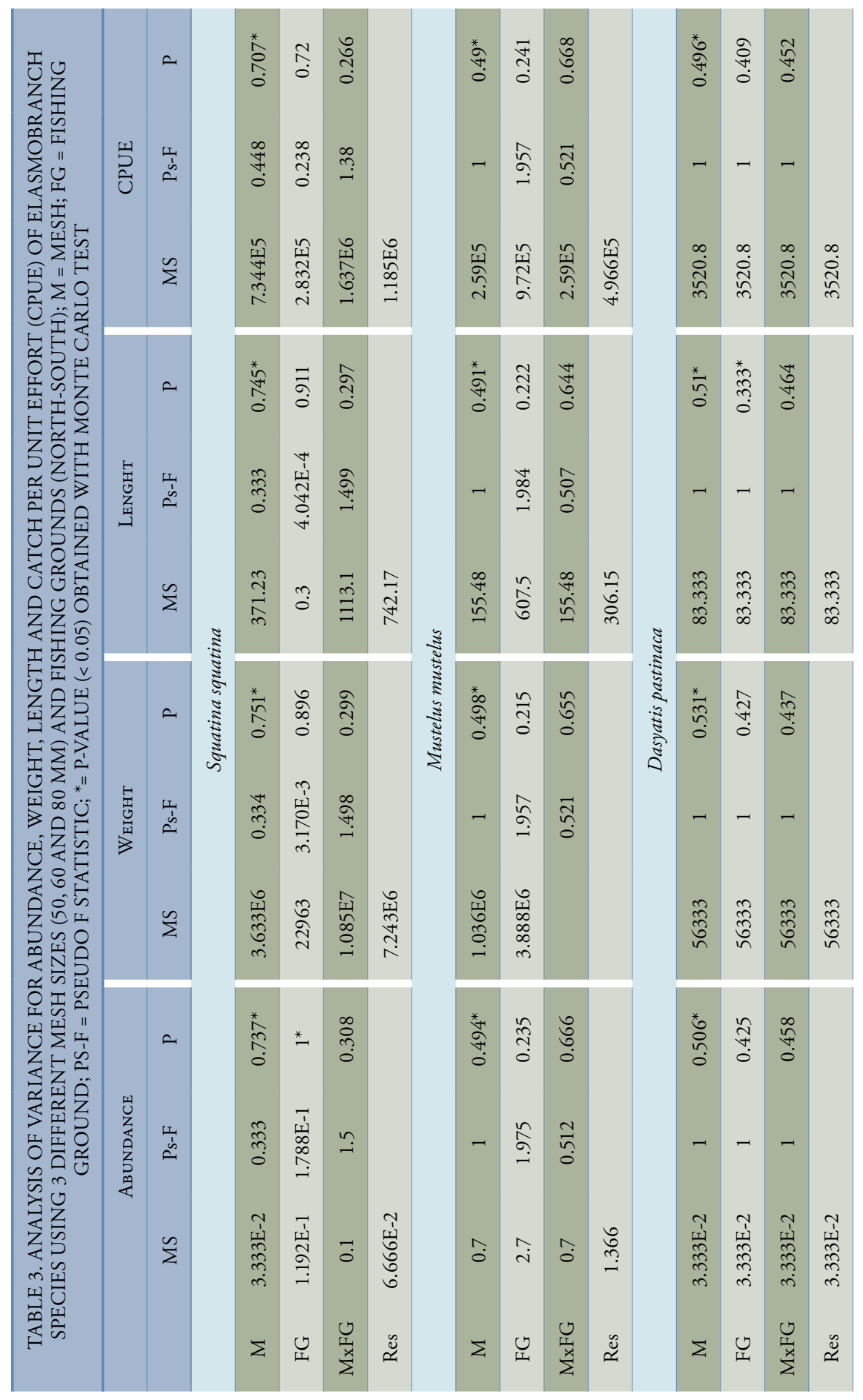




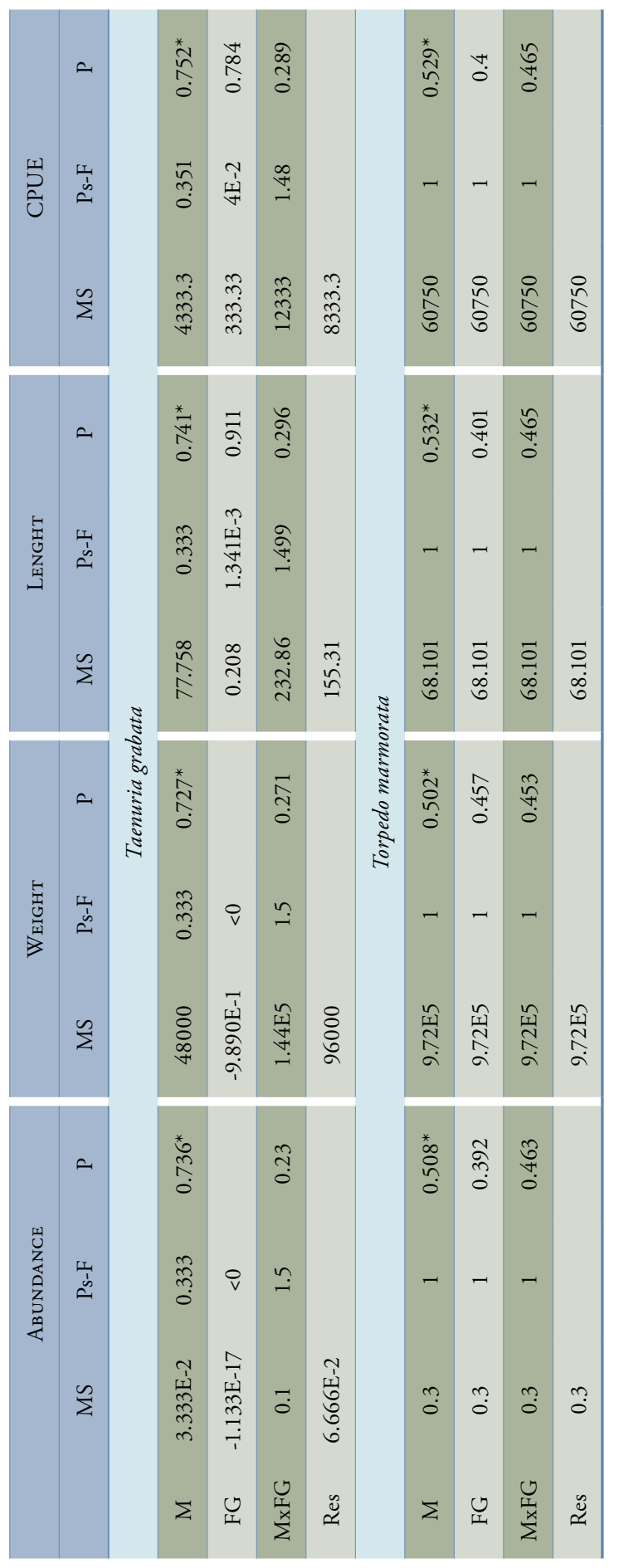


et al. 2007). This is probably due to trammel net canarian fishermen retain more variety of species than Iberian Peninsula artisanal fisheries based on custom and commercial acceptance differences between both regions.

In a trammel net fishery on the western coast of Portugal, Coelho et al. (2005) found that 16 elasmobranch species were caught (4.3\% of the total catch). Baeta et al. (2010) observed catches of 11 elasmobranch species which made up 4\% of the total catch. In our study elasmobranchs represented $3.62 \%$ of the total catch in number and $37.61 \%$ in weight. However, our catch included a smaller number of different elasmobranch species (5 elasmobranchs) probably due to the smaller range of depths sampled and fished or due to inherent characteristics of the Canary Islands elasmobranch fauna composition (Brito et al. 2002). Mustelus mustelus was the most frequently caught elasmobranch, which could be due to the abundance of the species in the study area. Furthermore, in Europe has been an unregulated rapid rise in reported landings of catches of smaller sharks, particularly smoothhounds (Mustelus spp.) and a detailed assessment is needed of where specific species are caught and in what numbers (Nieto et al. 2015).

Other measures to reduce discards in the studied trammel net fishery require further testing, but may include: (1) a reduction in soak time of the trammel nets, (2) choice of alternative fishing grounds, and (3) use of different mesh designs.

It was noted throughout the study that most of the discarded elasmobranchs were still alive. In some instances, the fishermen exterminated elasmobranchs in order to sell them or due to the cultural belief that reducing the number of predators will benefit stocks of their target species (Carmelo Dorta 2001, personal observation). Although squatiniforms do feed on commercial fish species including goatfishes (Mullidae) (Baremore et al. 2010), in the long term removal of elasmobranch predators would destabilize the balance of the ecosystem with adverse effects of commercial fish stocks. Elasmobranchs are very sensitive to overfishing; some species are already listed on the IUCN Red List as endangered, for example the Angelfish (Squatina squatina) which is critically endangered. Squatina squatina is an important demersal predator across large portions of the Canarian Archipelago but most of this region is subject to intense demersal fishing (Bravo de Laguna 1973; Bravo de Laguna and Escánez 1975). Angelshark (S. squatina) was formerly found throughout European waters, and now it is inferred that almost all of the remaining population is found around the Canary Islands. (Nieto et al. 2015). As a conclusion and due to the relatively high catch rates of $S$. squatina obtained by these fisheries there is an urgent need to confirm the species' status in the Canary Islands. It is possible that high numbers of $S$. squatina may still be present around the Canaries and the region could be a hotspot for elasmobranch conservation in Europe, as suggested by the high number of diver observations (De la Cruz et al. 2010). It would also be advisable to start a campaign among local Canarian fishing villages to explain the importance of protecting sharks and to promote good fishing practices such us releasing sharks alive since management regarding mesh size have been demonstrated to not be useful. 


\section{ACKNOWLEDGEMENT}

To the Cofradía de Pescadores de Candelaria and all its fishermen's, specially to Mario. We also thank all the friendly referees that improve an early version of this "observational" paper.

\section{AUTHORS'S CONTRIBUTION}

Conceptualization: JCM, JCH.

Methodology and field work: CD, JCH.

Data analysis: JCH.

Original draft: JCM.

Review and edition of the final draft: JCM, AB, JCH. 


\section{REFERENCES}

Anderson, M.J. 2001. Permutational tests for univariate or multivariat analysis of variance and regression. Can. J. Fish. Aquat. Sci. 58: 626-639.

Baeta, F., Batista, M., Maia, A., Costa, M.J. and Cabral, H. 2010. Elasmobranch bycatch in a trammel net fishery in the Portuguese west coast. Fish. Res. 102: 123-129.

Baremore, I.E., Murie, D.J. and Carlson, J.K. 2010. Seasonal and size-related differences in diet of the Atlantic angel shark Squatina dumeril in the northeastern Gulf of México. Aquat. Biol. 8: 125-136.

Bravo de Laguna, J. 1973. Elasmobranchii off the Canary Islands. ICES CM/J 1-17.

Bravo de Laguna, J. and Escánez, J. 1975. Informe sobre las posibilidades pesqueras de elasmobranquios en el archipiélago canario. Publicaciones Técnicas de la Junta de Estudios de Pesca 11: 169-192.

BOC 2005/04. Boletín Oficial de Canarias. http://www.gobiernodecanarias.org/boc/2005/004/ (accesed 1 Janaury 2015).

Bonfil, R. 1994. Overview of world elasmobranch fisheries. In FAO Fisheries Technical Paper 341. Food and Agriculture Organization of the United Nations. Rome. 119 pp.

Borges, T.C., Erzini, K., Bentes, L., Costa, M.E., Gonçalves, J.M.S., Lino, P.G., et al. 2001. By-catch and discarding practices in five Algarve (southern Portugal) métiers. J. Appl. Ichthyol 17: 104-114.

Brito, A., Pascual, P.J., Rabanal, R., Hernández, M., Lozano, I.J., Báez, A., et al. 1998. Peces cartilaginosos de Canarias. Los tiburones de los fondos profundos y su aprovechamiento pesquero. Consejería de Agricultura, Ganadería y Pesca del Gobierno de Canarias. Santa Cruz de Tenerife. 170 pp.

Brito, A., Pascual, P.J., Falcón, J.M., Sancho, A. and González-Lorenzo, G. 2002. Peces de las Islas Canarias. Francisco Lemus Editor. La Laguna. 419 pp.

Carbonell, A., Alemany, F., Merella, P., Quetglas, A. and Románc, E. 2003. The by-catch of sharks in the western Mediterranean (Balearic Islands) trawl fishery. Fish. Res. 6: 7-18.

Catchrole, T.L., Frid, C.L.J. and Gray, T.S. 2005. Discarding in the English north-east coast Nephrops norvegicus fishery: the role of social and environmental factors. Fish. Res. 72(1): 45-54.

Clarke, M.W., Borges, L. and Officer, R.A. 2005. Comparisons of trawl and longline catches of deepwater elasmobranchs west and north of Ireland. J. Northwest Atl. Fish. Sci. 35: 429-442.

Clucas I. 1997. A Study of the Options for Utilization of Bycatch and Discards from Marine Capture Fisheries. FAO fisheries circular No. 928 FIIU/C928. Rome: FAO (1997).

Coelho, R. and Erzini, K. 2002. Age and growth of the undulate ray, Raja undulata, in the Algarve (Southern Portugal). J. Mar. Biol. Assoc. UK 82(6): 987-990.

Coelho, R., Erzini, K., Bentes, L., Correia, C., Lino, P.G., Monteiro, P., et al. 2005. Semi-pelagic longline and trammel net elasmobranch catches in southern Portugal: catch composition, catch rates and discards. J. Northwest Atl. Fish. Sci. 35: 531-537.

Coelno, R. and Erzini, K. 2008. Effects of fishing methods on deep water shark species caught as by-catch off southern Portugal. Hydrobiologia 606: 187-193. 
Cortés, E. 1999. Standardized diet compositions and trophic levels of sharks. ICES J. Mar. Sci. 56: 707-717.

Couch, J. and Sмiтн, J.E. 1822. Some particulars of the natural history of fishes found in Cornwall. Trans. Linn. Soc. Lond. (1): 69-92.

Dulvy, N.K., Metcalfe, J.D., Glanville, J., Pawson, M.G. and Reynolds, J.D. 2000. Fishery stability, local extinctions and shifts in community structure in skates. Conserv. Biol. 14: 283-293.

DAY, F. 1880-1884. The fishes of Great Britain and Ireland, volume 2. Williams \& Noegate, London-Edinburgh.

De la Cruz, R., Esteban, A., Crilly, R, and Pascual-Fernández, J. 2010. Bucear con tiburones y rayas en España. Análisis de su potencial en España y de los beneficios económicos de la actividad en las Islas Canarias. Instituto Universitario de Ciencias Políticas y Sociales de la Universidad de La Laguna. 39 pp.

Erzini, K., Puente, E., Stergiou, K.I. and Hernando, J.A. 2001. Trammel net selectivity studies in the Algarve (Southern Portugal), gulf of Cadiz (Spain), Basque country (Spain) and Cyclades islands (Greece). Final Report UE-DG XIV-98/014, $435+$ annexes.

Erzini, K., Costa, M.E., Bentes, L. and Borges, T.C. 2002. A comparative study of the species composition of discards from five fisheries from the Algarve (southern Portugal). Fish. Manag. Ecol. 9: 31-40.

Erzini, K., Gonçalves, J.M.S., Bentes, L., Moutopoulos, D.K., Casal, J.A.H., Soriguer, M.C., et al. 2006. Size selectivity of trammel nets in southern European small-scale fisheries. Fish. Res. 79 (1-2): 183-201.

Frisk, M.G., Miller, T.J. and Fogarty, M.J. 2001. Estimation and analysis of biological parameters in elasmobranch fishes: A comparative life history study. Can. J. Fish. Aquat. Sci., 58: 969-981.

Gonçalves, J.M.S., Monteiro, P., Bentes, L., Coelho, R., Corado, M., Araújo, J., et al. 2004. Experimental By-catch Reducing Devices (BRD) in the demersal purse-seine fishery and evaluation of survivorship. FCT/POCTI/BSE/43113/2001, Final report, Universidade do Algarve, CCMAR, Faro, $126+$ annexes.

Gonçalves, J.M.S., Stergiou, K.L., Hernando, J.A., Puente, E., Moutopoulos, D.K., Arregi, L., et al. 2007. Discards from experimental trammel nets in southern European small-scale fisheries. Fish. Res. 88: 5-14.

Hall, M.A., Alverson, D.L. and Metuzals, K.I. 2000. By-catch: problems and solutions. Mar. Pollut. Bull. 41: 204-219.

Hazin, F.H.V., Olivera, P.G. and Broadhurst, M.K. 2002. Reproduction of the blacknose shark (Carcharhinus acronotus) in coastal waters off northeastern Brazil. Fish. Bull. 100: 143-148.

Heuter, R.E. 1998. Science and management of shark fisheries introduction. Fish. Res. 39: 105.

Jennings, S., Pinnegar, J.K., Polunin, N.V.C. and Warr, K.J. 2001. Impacts of trawling disturbance on the trophic structure of benthic invertebrate communities. Mar. Ecol. Prog. Ser. 213: 127-142.

Megalofonou, P., Yannopoulos, C., Damalas, D., De Metrio, G., Deflorio, M., de la SerNA, J.M., et al. 2005. Incidental catch and estimated discards of pelagic sharks from the swordfish and tuna fisheries in the Mediterranean Sea. Fish. Bull. 103: 620-634. 
Merino, J. and Maynou, F. 2003. Fish stock assessments in the Mediterranean: state of the art. Sci. Mar. 67: 37-49.

Merino, G., Morales-Nin, B., Maynou, F. and Grau, A.M. 2008. Assessment and bioeconomic analysis of the Majorca (NW Mediterranean) trammel net fishery. Aquat. Living. Resour. 21: 99-107.

Monteiro, P., Araújo, A., Erzini, K. and Castro, M. 2001. Discards of the Algarve (Southern Portugal) crustacean trawl fishery. Hydrobiologia 449: 267-277.

Nieto, A., Ralph, G.M., Comeros-Raynal, M.T., Kemp, J., García Criado, M., Allen, D.J. and Dulvy, N.K. 2015. European Red List of marine fishes. Luxembourg: Publications Office of the European Union.

Pratt, H.L. and Casey, J.G. 1990. Shark reproductive strategies as a limiting factor in directed fisheries, with a review of Holden's method of estimating growth-parameters. In: Pratt HL, Gruber SH and Taniuchi T, editors. Elasmobranchs as living resources: advances in the biology, ecology, systematics, and the status of the fisheries. US Department of Commerce. NOAA Technical Report NMFS 90: 97-109.

Smale, M.J. and Goosen, A.J. 1999. Reproduction and feeding of spotted gully shark, Triakis megalopterus, off the Eastern Cape, South Africa. Fish. Bull. 97: 987-998.

Stevens, J.D., Bonfil, R., Dulvy, N.K. and Walker, P.A. 2000. The effects of fishing on sharks, rays, and chimaeras (chondrichthyans), and the implications for marine ecosystems. ICES J. Mar. Sci. 57: 476-494.

Stobutzki, I.C., Miller, M., Heales, D.S. and Brewer, D.T. 2002. Sustainability of elasmobranch caught as bycatch in a tropical prawn (shrimp) trawl fishery. Fish. Bull. 100: 800-821.

Walker, P.A. and Hislop, J.R.G. 1998. Sensitive skates or resilient rays? Spatial and temporal shifts in ray species composition in the central and north-western North Sea between 1930 and the present day. ICES J. Mar. Sci., 55: 392-402.

Wintner, S.P. and Cliff, G. 1999. Age and growth determination of the white shark, Carcharodon carcharias, from the east coast of South Africa. Fish. Bull. 97: 153-169. 